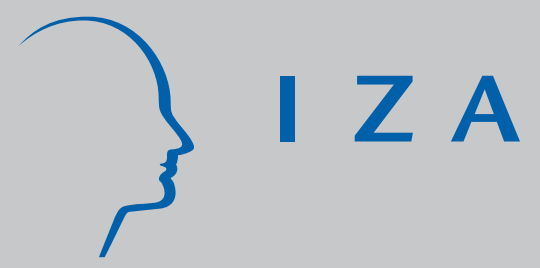

IZA DP No. 1124

Explaining the Growth

of Part-Time Employment:

Factors of Supply and Demand

Rob Euwals

Maurice Hogerbrugge

April 2004 


\title{
Explaining the Growth of Part-Time Employment: Factors of Supply and Demand
}

\author{
Rob Euwals \\ CPB, The Hague, CEPR \\ and IZA Bonn \\ Maurice Hogerbrugge \\ $C P B$, The Hague
Discussion Paper No. 1124
April 2004

\author{
IZA \\ P.O. Box 7240 \\ 53072 Bonn \\ Germany \\ Phone: +49-228-3894-0 \\ Fax: +49-228-3894-180 \\ Email: iza@iza.org
}

Any opinions expressed here are those of the author(s) and not those of the institute. Research disseminated by IZA may include views on policy, but the institute itself takes no institutional policy positions.

The Institute for the Study of Labor (IZA) in Bonn is a local and virtual international research center and a place of communication between science, politics and business. IZA is an independent nonprofit company supported by Deutsche Post World Net. The center is associated with the University of Bonn and offers a stimulating research environment through its research networks, research support, and visitors and doctoral programs. IZA engages in (i) original and internationally competitive research in all fields of labor economics, (ii) development of policy concepts, and (iii) dissemination of research results and concepts to the interested public.

IZA Discussion Papers often represent preliminary work and are circulated to encourage discussion. Citation of such a paper should account for its provisional character. A revised version may be available on the IZA website (www.iza.org) or directly from the author. 
IZA Discussion Paper No. 1124

April 2004

\section{ABSTRACT}

\section{Explaining the Growth of Part-Time Employment: Factors of Supply and Demand*}

Using the Dutch Labour Force Survey 1991-2001, the authors investigate the incidence of part-time employment in the country with the highest part-time employment rate of the OECD countries. Women fulfil most part-time jobs, but nevertheless a considerable fraction of men works part-time as well. Evidence from descriptive statistics and a macro-econometric model at the sectoral level of industry suggests that the growth of part-time employment in the 1990s relates strongly to the growth in female labour force participation. Factors of labour demand, like the shift from manufacturing to services, turn out to play a significant role as well.

JEL Classification: C33, J21, J23

Keywords: labour demand, labour supply, part-time employment, panel data

Corresponding author:

Rob Euwals

CPB

P.O. Box 80510

2508 The Hague

The Netherlands

Email: r.w.euwals@cpb.nl

\footnotetext{
* The authors wish to thank Didier Fouarge, Peter Kooiman, Hans Roodenburg, Hans Stegeman, Arthur van Soest, Adri den Ouden, Daniel van Vuuren and participants at seminars at CPB for valuable comments.
} 
In international comparisons on labour force participation and employment, the Netherlands show a high rate of part-time employment. This rate is high among women, and compared to other countries it is high among men as well. Despite the high level, the rate of part-time employment continues to grow at a pace faster than for the European Union and the US. Many Dutch and international studies on part-time employment focus on the supply side and in particular on the increasing labour force participation of women. In this study, we investigate the importance of factors of labour demand as well.

The international policy debate on part-time employment changed considerably in recent years. Before the 1990s, many economic observers highlighted the underutilization of labour and discussed the incidence of involuntary part-time employment. For instance, Leppel and Clain (1988) conclude that the growth in involuntary part-time employment in the US relates to the expansion of the service sector, while Blank (1989) suggests that part-time employment may be a stepping-stone into fulltime employment for US women. The $\operatorname{OECD}(1990,1995)$ relates involuntary part-time employment to underemployment and labour market slack. The particular interest in involuntary unemployment suggests that labour demand must be important.

The focus on involuntary unemployment seems ill-directed, as already in the beginning of the 1980s the OECD (1983) concluded that most part-time employment is voluntary. Moreover, authors like Hart (1987) and Hamermesh (1993) consider part-time employment as an outcome that can be in the interest of both firms and workers. In recent years, several economic observers started to open up their minds to part-time employment as a potential advantage rather than a trap for workers. Bolle (1997) concludes that if it is chosen freely and protected by law, part-time employment offers a good way of striking a balance between time to earn a living and time to devote to other activities. The OECD (2001) discusses part-time employment as a way in helping parents into paid employment and to balance work and family life. These insights suggest that in particular labour supply is important.

Since the 1980s already, Dutch policy makers recognised that part-time employment may be a way for workers to balance work and other (family and care) responsibilities. In 1993, the Dutch government reinforced the legal position of part-time workers by regulating the statutory minimum wage and the minimum holiday allowance. Previously, these rights did not apply to employees working less than one-third of normal full-time hours. In 1996, the Dutch social partners (which include employer and worker organisations) awarded an explicit right to equal treatment - pro rata - to part-time workers on wages, overtime payments, bonuses and training. So, recent policies made part-time employment more attractive to workers. The view that part- 
time employment may be in favour of workers is reflected in the Dutch labour supply literature, see for example Grift and Siegers (1993) and Euwals and van Soest (1999).

Most studies on part-time employment consider either the demand or the supply side, one of the exceptions being Doris (1998) on Ireland. Studies on demand include Rice (1990) and Friesen (1997) for the UK, Fallick (1999) for the US, and Columbino and Di Tommaso (2000) for Italy. Our contribution is that we consider factors of supply and demand simultaneously by using an empirical model at the sectoral level of industry. We include demand variables using data on sectors of industry and supply variables using survey data. We find that the growth in part-time employment relates strongly to the growth in female labour force participation. Factors of labour demand, like the shift from manufacturing to services, turn out to play a role as well.

In the remainder, we first discuss the Dutch labour market during the 1990s. Next, we analyse part-time employment on the basis of the Dutch Labour Force Survey 1991-2001.

\section{The Dutch Labour Market}

During the 1990s, the Netherlands experienced strong economic growth. Growth of GDP was almost 3\% per year, while OECD figures show that standardized unemployment dropped from $5.9 \%$ in 1990 to $2.8 \%$ in 2000. The employment-to-population ratio for persons aged 15-64 years grew from 61.1 to $74.1 \%$. A large part of this increase was due to women as their employment-to-population ratio grew from 46.7 to $63.4 \%$. Part-time employment increased as well: from 28.2 to $33.0 \%$ (of the total number of workers). ${ }^{2}$

As most part-time jobs are fulfilled by women, the relation between the growth in part-time employment and the growth in female employment seems obvious. Nevertheless, there is something left to explain as the rate of part-time employment increased for men and women.

To investigate the growth of part-time employment we use the Dutch Labour Force Survey (DLFS). Appendix A discusses the data source. Part-time employed persons will be those who usually work at least 12 hours and at most 34 hours per week. We consider these particular lower and upper bounds for several reasons. Individuals whose main daily task is not paid employment, like students and housewives, may nevertheless work some hours per week. We do not want to include these kinds of marginal employment into the analysis and therefore

\footnotetext{
${ }^{2}$ The OECD Employment Outlook defines part-time as usually working less than 30 hours per week in the main job.
} 
individuals that work less than 12 hours per week are not considered to be part of the labour force. The DLFS forces us to implement this lower bound as questions about employment are not asked to persons working less than 12 hours. Secondly, in many industries the full-time working week is 36 or 38 hours per week. To be sure not to include full-timers among the group of part-timers we use 34 hours per week as upper bound.

\begin{tabular}{|c|c|c|c|c|c|c|}
\hline \multirow[t]{3}{*}{ Table 2.1} & \multicolumn{6}{|c|}{ Part-time employment share by gender in $\%$, persons aged $15-64,1991-2001^{a}$} \\
\hline & \multicolumn{3}{|c|}{ Part-time employment ${ }^{\mathrm{b}}$} & \multicolumn{3}{|c|}{ Employment-to-population share ${ }^{\mathrm{b}}$} \\
\hline & 1991 & 2001 & a.a.g ${ }^{c}$ & 1991 & 2001 & a.a.g. ${ }^{\mathrm{c}}$ \\
\hline Total & 23.6 & 32.7 & 3.3 & 56.2 & 65.4 & 1.5 \\
\hline Women & 51.7 & 62.9 & 2.0 & 40.5 & 53.4 & 2.8 \\
\hline Men & 8.1 & 12.2 & 4.2 & 71.5 & 77.1 & 0.8 \\
\hline \multicolumn{7}{|c|}{$\begin{array}{l}\text { a Source: Dutch Labour Force Survey, own calculations. } \\
\text { b Our definitions of part-time employment and employment-to-population share deviate from the OECD definition because we use } 12 \\
\text { hours per week as an under bound, and for part-time we use } 34 \text { hours as an upper bound. } \\
\text { c }\end{array}$} \\
\hline
\end{tabular}

Table 2.1 shows that the average growth rate of part-time employment was $3.3 \%$. The OECD reports a lower average growth rate of $1.6 \%$ per year. An explanation for this difference is that in the Netherlands it has become rather normal to work 32 hour per week. In the OECD figure this is not counted as part-time employment (see footnote 2).

\begin{tabular}{|c|c|c|c|c|c|c|}
\hline \multirow[t]{3}{*}{ Part-time } & \multicolumn{6}{|c|}{ Part-time employment share by industry in $\%$, persons aged $15-64,1991-2001^{a}$} \\
\hline & \multicolumn{3}{|c|}{ Part-time employment } & \multicolumn{3}{|c|}{ Employment share } \\
\hline & 1991 & 2001 & a.a.g. ${ }^{b}$ & 1991 & 2001 & a.a.g. \\
\hline Total & 23.6 & 32.7 & 3.3 & 100.0 & 100.0 & 0.0 \\
\hline Health care & 51.6 & 67.6 & 2.7 & 13.2 & 14.6 & 1.0 \\
\hline Services & 28.9 & 31.9 & 1.0 & 14.9 & 17.7 & 1.8 \\
\hline Government & 22.8 & 34.6 & 4.2 & 14.8 & 13.7 & -0.8 \\
\hline Trade & 22.5 & 33.4 & 4.0 & 15.8 & 15.6 & -0.1 \\
\hline Finance, insurance & 17.3 & 25.0 & 3.7 & 4.5 & 5.6 & 2.3 \\
\hline Transport, communication & 14.7 & 22.3 & 4.3 & 6.4 & 6.4 & 0.0 \\
\hline Manufacturing, agriculture & 14.0 & 18.5 & 2.8 & 23.4 & 19.0 & -2.1 \\
\hline Construction & 6.4 & 8.1 & 2.4 & 7.0 & 7.3 & 0.5 \\
\hline
\end{tabular}

The employment-to-population ratio of women increased from 40.5 to $53.4 \%$. Although the ratio for men increased as well, it did so at a lower pace so that the share of women in total employment increased from 35.5 to $40.3 \%$. The growing share of women in total employment explains the increase in the part-time employment for about $25 \%$ : if the part-time employment 
share by gender would have remained constant after 1991 the part-time employment share would have grown to a level of $25.7 \%$ in 2001 . Table 2.1 shows a clear growth in the part-time employment share for both men and women.

The literature on part-time employment often suggests that the growth of the service sector offers a major explanation for the growth of part-time employment; see for instance Tilly (1995), Doris (1998) and Fallick (1999). Table 2.2 shows that certain sectors with many parttimers, like health care and indeed services grew. Moreover, some sectors with few part-timers, like manufacturing and agriculture declined. Nevertheless, the importance of the shift between sectors of industry for the growth of part-time employment is limited: if the part-time employment share by industry would have stayed constant after 1991 the part-time employment share would have grown to a level of $24.3 \%$ in 2001 . So the shift between sectors explains the growth in part-time employment for about $8 \%$.

\section{Figure 2.1 wage differential, part-time minus full-time in percentage of full-time hourly wages, 1991-2001 ${ }^{\mathrm{a}}$}

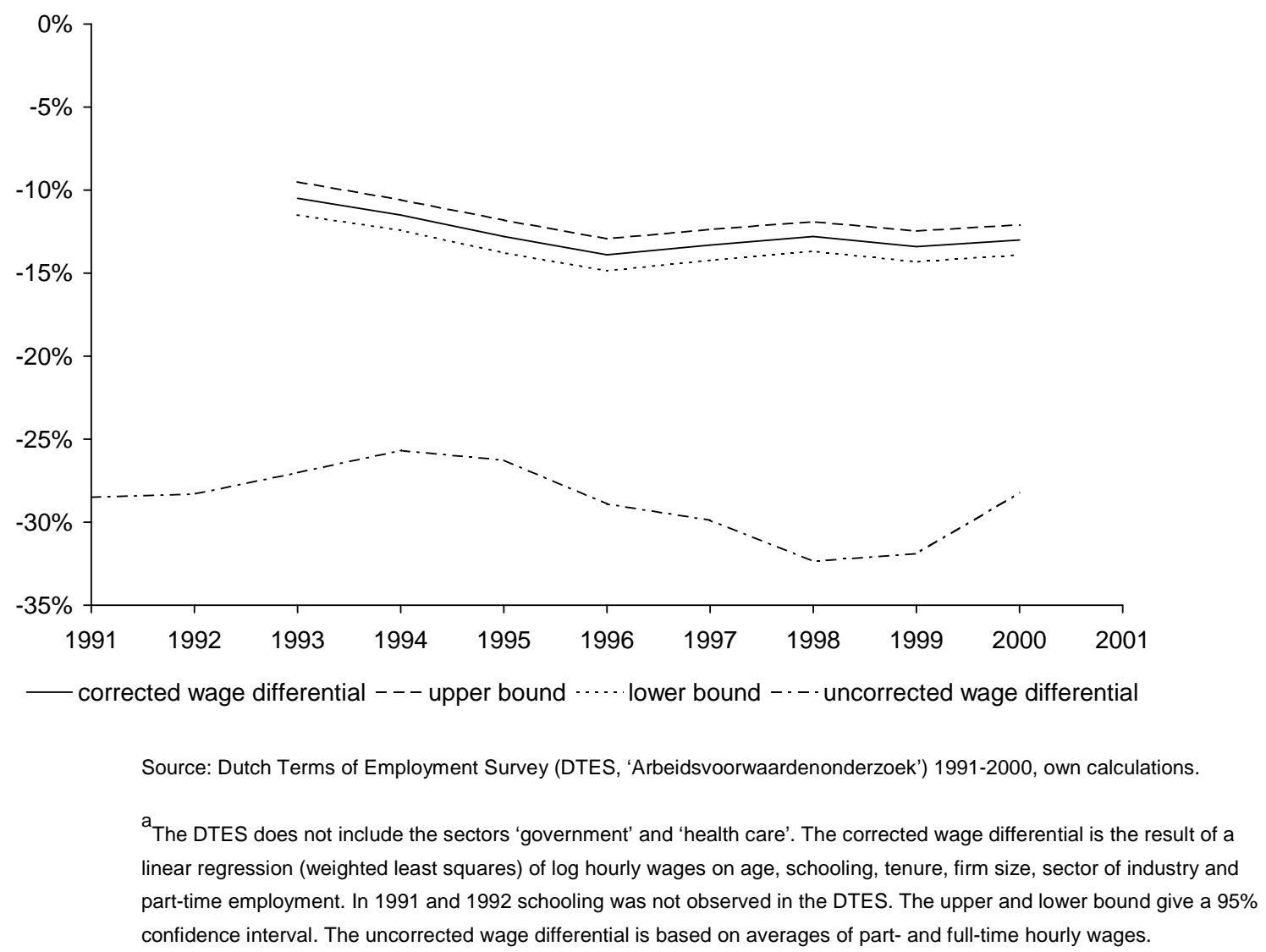

Table 2.2 also shows that for the level of part-time employment differences between sectors do play an important role. The high part-time employment rate of a sector like 'health care' sector is not explained by the large number of women in the sector as the part-time rate of the sector 
exceeds the part-time rate of women. The sectors 'agriculture', 'manufacturing', 'construction' and 'transport and communication' have low rates of part-time employment.

If the share of part-time employment increased because of an increase in labour supply, and not so much of labour demand, then we may expect that part-time wages dropped compared to fulltime wages. Of course, one may argue that wages of part- and full-timers are the same as employers are not allowed to pay different wages (on an hourly basis) for the same kind of work. Nevertheless, employers may be able to take advantage of the relatively large supply of part-time workers by allocating different kinds of work to full-timers and to part-timers by paying lower wages to the kind of work that is typically done by part-timers.

Figure 2.1 shows that the deviation of part-time wages in percentage of full-time wages was between 25 and $35 \%$. The deviation between the averages may, however, be affected by composition effects. Therefore we use linear regression to correct for these effects. We do not correct for job characteristics as this should make the wage gap disappear. The corrected wage gap is between 10 and 15\%, and there is some evidence that it increased over time. Given the substantial increase in the labour force participation of women, of which many want to work part-time, one may claim that the widening of the wage gap is moderate (in the market sector).

\section{$3 \quad$ Factors of Labour Demand}

In the previous section, we showed that the growth in part-time employment coincided with the growth in female employment. Arguments for the willingness to work part-time are easy to find, as it gives an opportunity for other activities like caring or studying. The labour supply literature therefore often explicitly allows for the wish to work part-time. The explanation on why firms may want to hire on a part-time basis gets however much less attention. In this section we consider possible reasons for employers to hire part-time workers.

Obviously, employers will hire part-time workers if their hourly productivity is larger than their hourly cost. But for which jobs and for which workers may this hold? A particular disadvantage of part-time employment is that there are fewer hours to cover quasi-fixed costs, like workplace and equipment costs and costs for firm and job specific knowledge. This makes part-time workers relatively expensive. So there must be particular advantages to part-time workers to make them attractive to employers.

It should be clear upfront that fringe benefits are unlikely to be an important argument for Dutch employers to hire part-time workers. As explained before, in the Netherlands employers are not allowed to treat part- and full-time workers differently. This contrasts to the situation in 
other countries, and in particular to the US where employers are allowed to offer less favourable fringe benefits to part-time workers. This makes part-time workers attractive to employers in these countries: Ressler et al. (1996) show that US employers increased their demand for parttime workers in reaction to minimum wage increases to cut wage costs, and Buchmueller (1999) shows that US employers that offer generous fringe benefits make greater use of lowwage part-time workers. Arguments like these are irrelevant for the Netherlands.

One particular reason for firms to hire part-time workers may be to achieve dynamic flexibility. Part-time workers may form a flexible pool of workers that can be used to adjust to the business cycle. In good times, part-timers may be willing to work more hours. While in bad times, parttimers may be willing to work fewer hours and new workers may be hired on a part-time basis. Empirical evidence for the relevance of such arguments exists: on the basis of firm level data, Friessen (1997) shows that part-time work plays a distinct role in the adjustment strategies of UK firms, while on the basis of country level data, Buddelmeier et al. (2003) show that parttime employment follows a stronger cyclical pattern than total employment.

The growth of part-time employment in the 1990s cannot be explained by dynamic flexibility of firms. As economic growth has been rather high, firms and workers should have adjusted towards full-time employment during this period. We are nevertheless interested in testing the empirical relevance of this explanation.

Another particular reason for firms to hire part-time workers may be to achieve organisational flexibility: firms that face predictable demand or production peeks may want to hire part-time workers to fill the demand for workers during these peeks. For example, the service and retail trade sector face demand peaks for consumer goods after regular working time and during weekends. Empirical evidence that support arguments like these exists: on the basis of Canadian firm level data, Zeytinoglu (1992) finds that organisational flexibility is a major argument to hire part-time workers, while on the basis of Dutch firm level data, Van Lomwel (2000) finds that the decoupling of working time and operating hours has lead to an increase in the demand for part-time workers. Furthermore, using a theoretical model for cooperating production factors, Deardorf and Stafford (1976) show that capital intensive industries have tight work schedules to use their capital optimally and therefore have little room for part-time employment.

Organisational flexibility can be a major explanation for the growth of part-time employment in the 1990s. The service sector has been growing already for decades, and the liberalization of the laws on opening hours of shops has clearly led to more demand for labour on non-standard working hours. The arguments discussed in this section are however difficult to capture in an empirical framework. One problem is that the need for organisational flexibility is difficult to 
measure, and that our data do not contain measures for hourly productivity and quasi-fixed costs. Nevertheless, we will exploit data on evening and weekend production and on capital intensity to capture the importance of organisational flexibility. To capture the impact of the business cycle, we will exploit data on sectoral growth and vacancies.

\section{$4 \quad$ Empirical Model}

In this section, we formalise two empirical models to explain the rate of part-time employment from a number of exogenous variables including factors of supply and demand. The first model is a simple linear regression model, which may be interpreted as an approximation or a reduced form of more complicated models that account for the structure of the labour market. The second model is a simultaneous equation equilibrium model for the supply and demand of parttime employment. The model is proposed by Ehrenberg et al. (1988) for the US, and we discuss the accurateness of the model for the Netherlands.

Define $y_{i t}$ as the proportion of part-time employment in total employment, both measured in the numbers of persons, of sector of industry $i=1, \ldots, I$ at year $t=1, \ldots, T$. Define:

$$
y_{i t}=\alpha_{i}+x_{i t}^{s} \alpha^{s}+x_{i t}^{d} \alpha^{d}+x_{i t} \alpha+\varepsilon_{i t}
$$

with $\left(x_{i t}{ }^{s}, x_{i t}{ }^{d}, x_{i t}\right)$ vectors of supply, demand and general exogenous variables. The sector specific effect $\alpha_{i}$ will be treated as a parameter, i.e. fixed effect, and $\left(\alpha^{s}, \alpha^{d}, \alpha\right)$ are vectors of parameters. We assume the error term $\varepsilon_{i t}$ to be independently and identically distributed.

Under the assumptions formulated above the model can be estimated with a method like ordinary least squares. The interpretation of the estimation results is rather straightforward as for many variables it will be clear whether they should be interpreted as a supply or a demand effect. For instance, the increase in the participation rate of certain groups in the population can be interpreted as a labour supply effect while the vacancy rate of a sector of industry can be interpreted as a labour demand effect.

An important assumption underlying the model is that the rate of part-time employment at a certain year is affected by the exogenous variables of that year and not by lagged exogenous variables. In theory we may expect employment in the Netherlands to adjust slowly over time because of inflexibilities in the labour market (like employment protection and social security). Therefore may need to formulate a model with adjustment over time, leading to a model with time series properties. The time period of our data is however too short for such an approach. Furthermore, inflexibilities in the labour market may lead to slow adjustments in the amount of 
employment, but with respect to part-time employment the Dutch labour market is rather flexible. Employees have a lot of freedom in working part-time, while employers may use flexible employment contracts and temporary working agencies to fulfil their demand for parttime workers in a reasonably short time.

Next, we employ an empirical model that is proposed by Ehrenberg et al. (1988) to analyse the incidence of part-time employment in the US. To our knowledge, it is one of the few models in the literature on part-time employment that estimates the impact of factors of supply and demand simultaneously, and the study has been an important source of inspiration for our own study. We will discuss the relevance of the model for the US and Dutch labour market.

Define $y_{i t}{ }^{s}$ and $y_{i t}{ }^{d}$ as the supply and demand for part-time employment as a proportion of total employment for the sector of industry $i=1, \ldots, I$ and year $t=1, \ldots, T$. Define:

$$
\begin{aligned}
& y_{i t}^{s}=\mu_{i}^{s}+w_{i t} \beta^{s}+x_{i t}^{s} \gamma^{s}+x_{i t} \delta^{s}+\varepsilon_{i t}^{s} \\
& y_{i t}^{d}=\mu_{i}^{d}+w_{i t} \beta^{d}+x_{i t}^{d} \gamma^{d}+x_{i t} \delta^{d}+\varepsilon_{i t}^{d} \\
& y_{i t}^{s}=y_{i t}^{d}
\end{aligned}
$$

with $w_{i t}$ an endogenous variable that represents the wage gap between part-time and full-time. The sector specific effects $\left(\mu_{i}^{s}, \mu_{i}^{d}\right)$ will be treated as parameters, i.e. fixed effects, $\left(\beta^{s}, \beta^{d}\right)$ are parameters and $\left(\gamma^{s}, \gamma^{d}, \delta^{s}, \delta^{d}\right)$ are vectors of parameters. We assume the vector of error terms $\left(\varepsilon_{i t}{ }^{s}, \varepsilon_{i t}{ }^{d}\right)$ to be independently and identically distributed.

The reduced form of the simultaneous equation model is the model of equation (4.1). To estimate the full structural model we need a measure for the wage gap $w_{i t}$. For our empirical exercise, we will use gross wages $W_{j t}$ for individuals $j=1, \ldots, J$ and time periods $t=1, \ldots, T$ observed in the Dutch Terms of Employment Survey ('Arbeidsvoorwaardenonderzoek'). Appendix B discusses details of the data source. We use the following model:

$$
\log \left(W_{j t}\right)=z_{j t} \theta+d_{j t} w_{t}+v_{j t}
$$

with $z_{j t}$ a vector of individual characteristics, including a vector of dummies for the sector of industry, and $\theta$ a vector of parameters. The model does not contain an index $i$ for the sector of industry as individual $j$ works in a particular industry, which is represented by dummies. The vector of exogenous variables $d_{j t}=\left[d_{l j t}, \ldots, d_{l j t}\right]$ contains interactions between working in sector of industry $i=1, \ldots, I$ and working part-time, while the vector of parameters $\mathrm{w}_{t}=\left[w_{I t}, \ldots, w_{I t}\right]$ 
contains sector specific parameters to represent the wage gap between part-time and full-time in a sector of industry. To smooth the impact of the exogenous variables over time, the parameters are assumed to be second order polynomials of time. In other words, we define parameter $w_{i t}$ as a function of time and parameters $\left(\omega_{i 0}, \omega_{i 1}, \omega_{i 2}\right)$ :

$w_{i t}=\omega_{i 0}+\omega_{i 1}(t-1990)+\omega_{i 2}(t-1990)^{2}$

To estimate the structural model of equations (4.2) to (4.4), we first need to estimate the model of equation (4.5). In a second step, we use the estimated parameters $w_{i t}$ as an endogenous variable for the structural model. For the calculation of the standard errors of the structural model we ignore the fact that the wage gap $w_{i t}$ was estimated. As the numbers of observations for the first step is very large, the standard errors of the second step will not be very biased.

The model of equations (4.2) to (4.4) assumes that the rate of part-time employment reaches its equilibrium instantaneously. The model of Ehrenberg et al. (1988) may be reasonable for the flexible labour market of the US, but for the Netherlands the assumption seems questionable. For the linear regression model of equation (4.1) we argued that the Dutch labour market is rather flexible with respect to the rate of part-time employment, but for wages this is much less likely to be the case. In the Netherlands wages are determined by central wage bargaining and the collective agreements between employer and employee organisations often hold for more than one year. For this reason the development of wages should be described by a dynamic adjustment model in which wages are determined by the realizations of the exogenous variables known to the negotiation partners at the time of the bargaining process. Slow adjustments of wages may lead to excess part-time labour supply, implying that individuals may need to accept a full-time job or else will become involuntary unemployed. Such issues are however beyond the scope of this study. Therefore we nevertheless employ the empirical model of Ehrenberg $e t$ al. (1988) and compare our estimation results to his results.

While the descriptive analysis of Section 2 reveals a statistically significant correlation between part-time employment and female labour force participation, the econometric analysis assumes there is a causal relation from participation to part-time employment. The reason is that the econometric analysis assumes participation to be exogenous. This may be a critical assumption: During the 1990s, participation may have been encouraged by the increasing demand for (parttime) employment. This may cause 'endogeneity bias', and in theory we would need explain participation by adding an additional equation to the model. This is however beyond the scope of our study, and instead we decide to interpret the estimation results with care. 


\section{Data}

Estimation will be based on data derived from the Dutch Labour Force Survey (DLFS) and the national accounts for 19 different sectors of industry. For illustration purposes we aggregated these 19 sectors to 8 sectors in Table 2.2. For regression analysis such an aggregation is not necessary. Compared to Table 2.2, we split up 'manufacturing and agriculture' into 9 different manufacturing industries and a sector 'agriculture'. Furthermore, we separate the sector 'real estate' from the sector 'finance and insurance', and we subdivide the sector 'transport and telecommunication' into sectors 'transport' and 'telecommunication'. As the resulting sectors vary in size, the models of Section 4 will be estimated using a weighted estimation procedure. We use labour input of a sector (measured in full-time equivalents) as weights.

\begin{tabular}{|c|c|c|c|c|c|c|c|c|c|c|}
\hline \multirow[t]{2}{*}{ Table 5.1} & deman & , 1992- & 001 & & & & & & & \\
\hline & 1992 & 1993 & 1994 & 1995 & 1996 & 1997 & 1998 & 1999 & 2000 & 2001 \\
\hline \multicolumn{11}{|l|}{ Factors of supply ${ }^{\mathrm{a}}$} \\
\hline Fraction women & 0.349 & 0.356 & 0.363 & 0.368 & 0.374 & 0.384 & 0.391 & 0.401 & 0.399 & 0.406 \\
\hline Fraction women aged 25-44 & 0.583 & 0.583 & 0.588 & 0.598 & 0.600 & 0.602 & 0.604 & 0.598 & 0.590 & 0.581 \\
\hline Fraction women aged $45-64$ & 0.196 & 0.206 & 0.215 & 0.223 & 0.224 & 0.234 & 0.246 & 0.252 & 0.265 & 0.270 \\
\hline Fraction women with children & 0.344 & 0.352 & 0.358 & 0.359 & 0.367 & 0.375 & 0.391 & 0.396 & 0.401 & 0.414 \\
\hline Fraction men aged $25-44$ & 0.582 & 0.584 & 0.581 & 0.583 & 0.582 & 0.575 & 0.570 & 0.560 & 0.552 & 0.547 \\
\hline Fraction men aged $45-64$ & 0.284 & 0.289 & 0.299 & 0.304 & 0.310 & 0.318 & 0.326 & 0.336 & 0.342 & 0.345 \\
\hline Fraction men with children & 0.420 & 0.417 & 0.416 & 0.412 & 0.415 & 0.409 & 0.407 & 0.406 & 0.404 & 0.410 \\
\hline \multicolumn{11}{|l|}{ Factors of demand } \\
\hline Growth of production $^{\mathrm{b}}$ & 0.037 & 0.031 & 0.044 & 0.045 & 0.038 & 0.060 & 0.057 & 0.058 & 0.078 & 0.060 \\
\hline Vacancy rate $^{c}$ & 0.011 & 0.007 & 0.008 & 0.010 & 0.011 & 0.015 & 0.020 & 0.025 & 0.027 & 0.025 \\
\hline Capital intensity $^{d}$ & 0.192 & 0.197 & 0.202 & 0.203 & 0.202 & 0.201 & 0.201 & 0.202 & 0.205 & 0.208 \\
\hline Production in weekends ${ }^{a}$ & 0.410 & 0.414 & 0.425 & 0.427 & 0.437 & 0.438 & 0.445 & 0.454 & 0.468 & 0.471 \\
\hline Production in evenings $^{a}$ & 0.165 & 0.166 & 0.167 & 0.164 & 0.173 & 0.179 & 0.180 & 0.183 & 0.187 & 0.187 \\
\hline \multicolumn{11}{|c|}{$\begin{array}{l}\text { a Source: Dutch Labour Force Survey, own calculations. Factors of supply are at the sectoral level, Appendix C discusses details. } \\
\text { b Source: National Accounts, growth of gross production measured in factor costs. }\end{array}$} \\
\hline \multicolumn{11}{|c|}{ 'Sources: Statistics Netherlands and National Accounts, vacancies per full-time labour input equivalents. } \\
\hline
\end{tabular}

Most factors of demand that we consider in this study can be derived at the sectoral level from national accounts. The variables on growth of production and capital intensity are based on figures on gross production, labour input and investments per sector. The growth of production will be interpreted as a measure for the business cycle. Table 5.1 shows that the growth of production reached its highest point at the end of the 1990s. The stock of capital is calculated using the perpetual inventory method (Van der Wiel, 2001). Capital intensity is measured in millions of euros per full-time equivalent employee, and has grown at the aggregated level despite the growing importance of services. The vacancy rate at the sectoral level of industry is made available by Statistics Netherlands, and it reached its highest point at the end of the 1990s 
as well. Weekend and evening production of a sector of industry are calculated on the basis of the DLFS. They show an increasing trend, and this is in line with the increasing demand for goods and services and the accompanying liberalisation of the laws on opening hours.

Factors of labour supply, like the participation rate of women, are usually measured on the national level. Measurement of labour supply on the sectoral level is difficult as for most individuals it is not clear to which sectors of industry they supply labour. Even an individual that works in a certain sector could potentially work in another sector. One way to solve the problem is to use labour supply variables on the national level in the empirical analysis, but as we have only 11 years of observations we could include only a few of such variables. Another way to solve the problem is to use the individuals that work in a certain sector to construct labour supply variables for that particular sector (Ehrenberg et al., 1988). The interpretation of such variables in explaining the level of part-time employment is however problematic: Is the rate of part-time employment in a sector high because so many women work in the sector, or work so many women in the sector because they can work part-time? In other words, the direction of causality is unclear.

In this section we will use female labour force participation as our major example as it is easy to understand, but in the empirical exercise we will consider the participation of age groups and groups that have children as well. What we like to have as an explanatory variable is the share of women in the group of people that could work in a sector. If the share of women in the group is large then the sector will have to take the preferences of women into account. And we do know which persons could work in a sector by using data on the type of education of the workers in a sector. Say, for example, that the sector 'health care' only employs individuals that have an education in 'health care'. Then the share of women in the labour supply of the sector 'health care' is the share of women among those who have an education in 'health care.' This group includes individuals that are working other sectors and that are unemployed. Reversed causality, so from part-time employment to participation, only occurs in case individuals choose a certain education (f.i. 'health care') because they want to work part-time later on in their life.

We will construct factors of labour supply by using educational data from the DLFS. Of course, no sector of industry needs one particular education. For this reason, we calculate the educational mix of the workers in a particular sector (we observe 20 different combinations of levels and directions). For example, about $39 \%$ of workers in the sector 'health care' have a medium vocational education in 'health care'. Next, we calculate the percentage of women in the total labour force that fulfils the particular educational needs of a sector by using a weighting procedure on the basis of the education mix. For instance, all individuals with a medium level education in 'health care' get a weight of 0.39 for the sector 'health care.' 
Individuals with another kind of education get a lower weight for the sector 'health care' as they are less important for the relevant labour supply of the sector. Appendix $\mathrm{C}$ presents details on the weighting procedure and the construction of the sector specific labour supply variables.

For estimation, we will not use data for the year 1991 as in the DLFS the educational variables for that year deviate from later years. Table 5.1 shows the share of women in the labour force to increases over time. One should keep in mind that the factors of supply vary over the different sectors of industry: for instance, the share of women in the relevant labour supply for a sector in the year 2000 varies from $18.1 \%$ in construction to $62.0 \%$ in health care. Besides the sector specific share of women, we construct sector specific labour supply variables for age groups and for having children. The share of elderly among the labour force participants for both women and men increased from 19.6 and $28.4 \%$ in 1992 to 27.0 and $34.5 \%$ in 2001. The share of women with children among the female labour force participants increased from 34.4 to $41.4 \%$ despite the decrease in birth rates.

\section{$6 \quad$ Estimation Results}

\section{Single equation model}

We estimated the model of equation (4.1) by using weigthed least squares. The model includes all variables of supply and demand. To highlight the importance of female labour force participation, we start our investigation with a model that includes only the share of women. In later steps, we add more variables to see how the importance of the variable changes.

The first column of Table 6.1 shows a statistically insignificant relation between the share of women and the share of part-time employment. The model includes a time trend as the high growth rate of both variables may lead to spurious correlation (excluding the time trend makes the variable on the share of women highly significant). As the second column of the table shows, the share of women stays insignificant after introducing the factors of labour demand. The time trend is highly significant: per year the rate of part-time employment increases by 0.7 to $0.8 \%$-points per year.

According to the second column of Table 6.1 the variables that represent the business cycle clearly have a negative impact: the rate of part-time employment is high when the growth of production and the vacancy rate are low. Capital intensity does not significantly relate to parttime employment and stays insignificant in any other specification that we try in this study. The interpretation of the theory by Deardorf and Stafford (1976) that high capital intensity leads to a low demand for part-time employment is not supported by our results. Production in evenings leads to more part-time employment, confirming that production on non-standard working 
hours leads to more part-time employment. The weakly significant negative sign of weekend production seems to contradict this conclusion, but later specifications of the model show that the impact of weekend production is insignificant.

\begin{tabular}{|c|c|c|c|c|c|}
\hline \multirow[t]{2}{*}{ Estimation result } & igle equation & del & & & \\
\hline & Model 1a & Model $1 b$ & Model 2a & Model 2b & Model 2c \\
\hline \multirow[t]{2}{*}{ Intercept } & 0.17023 & -0.00368 & -0.03944 & -0.05279 & 0.9023 \\
\hline & $(0.21184)$ & $(0.20592)$ & $(0.05183)$ & $(0.07033)$ & $* *(0.30195)$ \\
\hline \multirow[t]{2}{*}{ Time trend (=year-1990) } & 0.00716 & 0.00789 & 0.00288 & 0.00449 & 0.00051 \\
\hline & $* *(0.00180)$ & ${ }^{* \star}(0.00182)$ & ${ }^{* *}(0.00099)$ & ${ }^{* \star}(0.00146)$ & $(0.00260)$ \\
\hline \multicolumn{6}{|l|}{ Factors of supply } \\
\hline \multirow[t]{2}{*}{ Fraction women (aggregated level) } & 0.17325 & 0.50413 & & & \\
\hline & $(0.55885)$ & $(0.53822)$ & & & \\
\hline \multirow[t]{2}{*}{ Fraction women (sectoral level) } & & & 0.87031 & 0.71799 & 0.47964 \\
\hline & & & ${ }^{* \star}(0.16336)$ & ${ }^{\star \star}(0.16969)$ & ${ }^{* *}(0.13901)$ \\
\hline \multirow[t]{2}{*}{ Fraction women aged $25-44$} & & & & & 0.47556 \\
\hline & & & & & ${ }^{* *}(0.18630)$ \\
\hline \multirow[t]{2}{*}{ Fraction women aged 45-64 } & & & & & 0.84211 \\
\hline & & & & & $* *(0.22445)$ \\
\hline \multirow[t]{2}{*}{ Fraction women with children } & & & & & -0.33225 \\
\hline & & & & & $(0.23864)$ \\
\hline \multirow[t]{2}{*}{ Fraction men aged $25-44$} & & & & & -1.37893 \\
\hline & & & & & $* *(0.36628)$ \\
\hline \multirow[t]{2}{*}{ Fraction men aged $45-64$} & & & & & -0.67860 \\
\hline & & & & & $* *(0.34512)$ \\
\hline \multirow[t]{2}{*}{ Fraction men with children } & & & & & -0.60087 \\
\hline & & & & & * $(0.33776)$ \\
\hline \multicolumn{6}{|l|}{ Factors of demand } \\
\hline \multirow[t]{2}{*}{ Growth of production } & & -0.04564 & & -0.05739 & -0.11621 \\
\hline & & $(0.03980)$ & & $(0.03790)$ & ${ }^{* *}(0.03021)$ \\
\hline \multirow[t]{2}{*}{ Vacancy rate } & & -0.71399 & & -0.40243 & -0.91625 \\
\hline & & ${ }^{* *}(0.23720)$ & & *(0.23324) & ${ }^{* *}(0.20718)$ \\
\hline \multirow[t]{2}{*}{ Capital intensity } & & 0.00726 & & 0.01560 & 0.03318 \\
\hline & & $(0.04613)$ & & $(0.04391)$ & $(0.03395)$ \\
\hline \multirow[t]{2}{*}{ Production in weekends } & & -0.11595 & & -0.05963 & 0.02989 \\
\hline & & $*(0.06027)$ & & $(0.05819)$ & $(0.04579)$ \\
\hline \multirow[t]{2}{*}{ Production in evenings } & & 0.39539 & & 0.33305 & 0.31728 \\
\hline & & ${ }^{* *}(0.12606)$ & & ${ }^{* *}(0.12080)$ & ${ }^{* *}(0.10745)$ \\
\hline
\end{tabular}

Note: The model is estimated by weighted least squares. The dependent variable is the rate of part-time employment of the sector of industry. Table 5.1 discusses the definitions of the explanatory variables. The estimation results on sectoral dummies are not reported. Between parentheses are standard errors. Variables marked with * and ** are significant at a 10 and $5 \%$ significance level.

In the last three columns of Table 6.1 we use labour supply variables at the sectoral level of industry. The size of the impact of the share of women decreases when more explanatory variables are included in the model. The impact of the share of women nevertheless stays 
significantly different from zero. A one-percentage point increase in the share of women among the labour force participants leads to a half percentage-point increase in part-time employment. The impact of the demand variables stays in line with the results of column 2 of Table 6.1.

The last column of Table 6.1 shows that women of age 25 to 64 are more likely to work parttime than women of the reference group of age 15 to 24 , while the oldest women are most likely to work part-time. Men of age 25 to 64 are less likely to work part-time. Women with children are not more or less likely to work part-time than women without children. This contradicts the literature on labour supply which almost always finds strong effects of children on the labour supply of women. Men with children have a weakly significant lower probability to work parttime. The time trend has become insignificant in specification of column 5. This suggests that the specification explains the increase in part-time employment rather well.

\section{Simultaneous equation model}

We estimate the model of equations (4.2) to (4.4) by using weighted three stage least squares. As the wage gap is not observed for the year 1992, and not for the sectors 'government' and 'health care', the number of observations is smaller than for the reduced form model. Given the good results of the complete single equation model (see column 5 of Table 6.1) we only present the estimation results of the complete model.

Table 6.2 shows that the signs of the wage gap are economically plausible. A larger wage gap, implying a more negative difference between full-time and part-time wages, leads to a smaller supply and a larger demand for part-time employment. The impact of wages is however insignificantly different from zero for demand. This is disappointing as it is hard to believe that the wages do not matter for employers. An additional reduced form regression to explain the wage gap (which is an endogenous variable in the simultaneous equation model) reveals the nature of the econometric side of the problem: The factors of supply and demand are each jointly significant (p-values 0.0109 and 0.0180 ), but nevertheless almost all variables separately are insignificant. So the instruments seem to be of moderate quality and that may explain the imprecise measurement of the impact of the wage gap on part-time employment.

As it is hard to believe that wages do not matter for employers, we need to question the adequacy of the economic model. A possible reason for the results is that employers do have difficulties to adjust within the market of part-time employment. On the one hand, employers may be able to adjust in a reasonably short time by using flexible employment contracts and temporary working agencies, but on the other hand, employers are not allowed to pay different wages for the same kind of work. Therefore employers can achieve differences in wages only by allocating different kinds of work to full-timers and part-timers, and such an adjustment 
mechanism may need time. A remarkable fact is that Ehrenberg et al. (1988) find exactly the same result for the US: labour supply significantly relates to wages, but labour demand does not! So although the US labour market is mostly characterized as being very flexible compared to other countries, the assumptions of simultaneous equation model may be too 'heroic' for the US as well. An appealing explanation is that the market for part-time employment will not reach equilibrium instantaneously as also in the US firms need time to adjust their labour input.

\begin{tabular}{|c|c|c|}
\hline \multirow[t]{2}{*}{ Estimation res } & & \\
\hline & Supply & Demand \\
\hline \multirow[t]{2}{*}{ Intercept } & 0.29924 & 0.06671 \\
\hline & $(0.25326)$ & $(0.00661)$ \\
\hline \multirow[t]{2}{*}{ Wage gap } & 0.35121 & -0.08612 \\
\hline & ${ }^{* *}(0.17033)$ & $(0.20017)$ \\
\hline \multicolumn{3}{|l|}{ Factors of supply } \\
\hline \multirow[t]{2}{*}{ Fraction women (sectoral level) } & 0.42477 & \\
\hline & ${ }^{* *}(0.13010)$ & \\
\hline \multirow[t]{2}{*}{ Fraction women aged 25-44 } & 0.35786 & \\
\hline & $(0.21845)$ & \\
\hline \multirow[t]{2}{*}{ Fraction women aged $45-64$} & 0.63357 & \\
\hline & ${ }^{* *}(0.21417)$ & \\
\hline \multirow[t]{2}{*}{ Fraction women with children } & -0.06413 & \\
\hline & $(0.20610)$ & \\
\hline \multirow[t]{2}{*}{ Fraction men aged $25-44$} & -0.35086 & \\
\hline & $(0.40591)$ & \\
\hline \multirow[t]{2}{*}{ Fraction men aged $45-64$} & -0.49223 & \\
\hline & $(0.31147)$ & \\
\hline \multirow[t]{2}{*}{ Fraction men with children } & -0.21373 & \\
\hline & $(0.47506)$ & \\
\hline \multicolumn{3}{|l|}{ Factors of demand } \\
\hline \multirow[t]{2}{*}{ Growth of production } & & 0.00594 \\
\hline & & $(0.03460)$ \\
\hline \multirow[t]{2}{*}{ Vacancy rate } & & 0.49603 \\
\hline & & ${ }^{* *}(0.23043)$ \\
\hline \multirow[t]{2}{*}{ Capital intensity } & & 0.09274 \\
\hline & & ${ }^{*}(0.04881)$ \\
\hline \multirow[t]{2}{*}{ Production in weekends } & & 0.12174 \\
\hline & & $(0.08316)$ \\
\hline \multirow[t]{2}{*}{ Production in evenings } & & 0.39824 \\
\hline & & ${ }^{* *}(0.12078)$ \\
\hline \multicolumn{3}{|c|}{$\begin{array}{l}\text { Note: The model is estimated by weighted three stage least squares. The dependent variable is the rate of part-time employment of the } \\
\text { sector of industry. Table } 5.1 \text { discusses the definitions of the explanatory variables. The estimation results on sectoral dummies are not } \\
\text { reported. Between parentheses are standard errors. Variables marked with }{ }^{*} \text { and }{ }^{* *} \text { are significant at a } 10 \text { and } 5 \% \text { significance level. }\end{array}$} \\
\hline
\end{tabular}


Figure 6.1: Simulated development of part-time employment, supply side

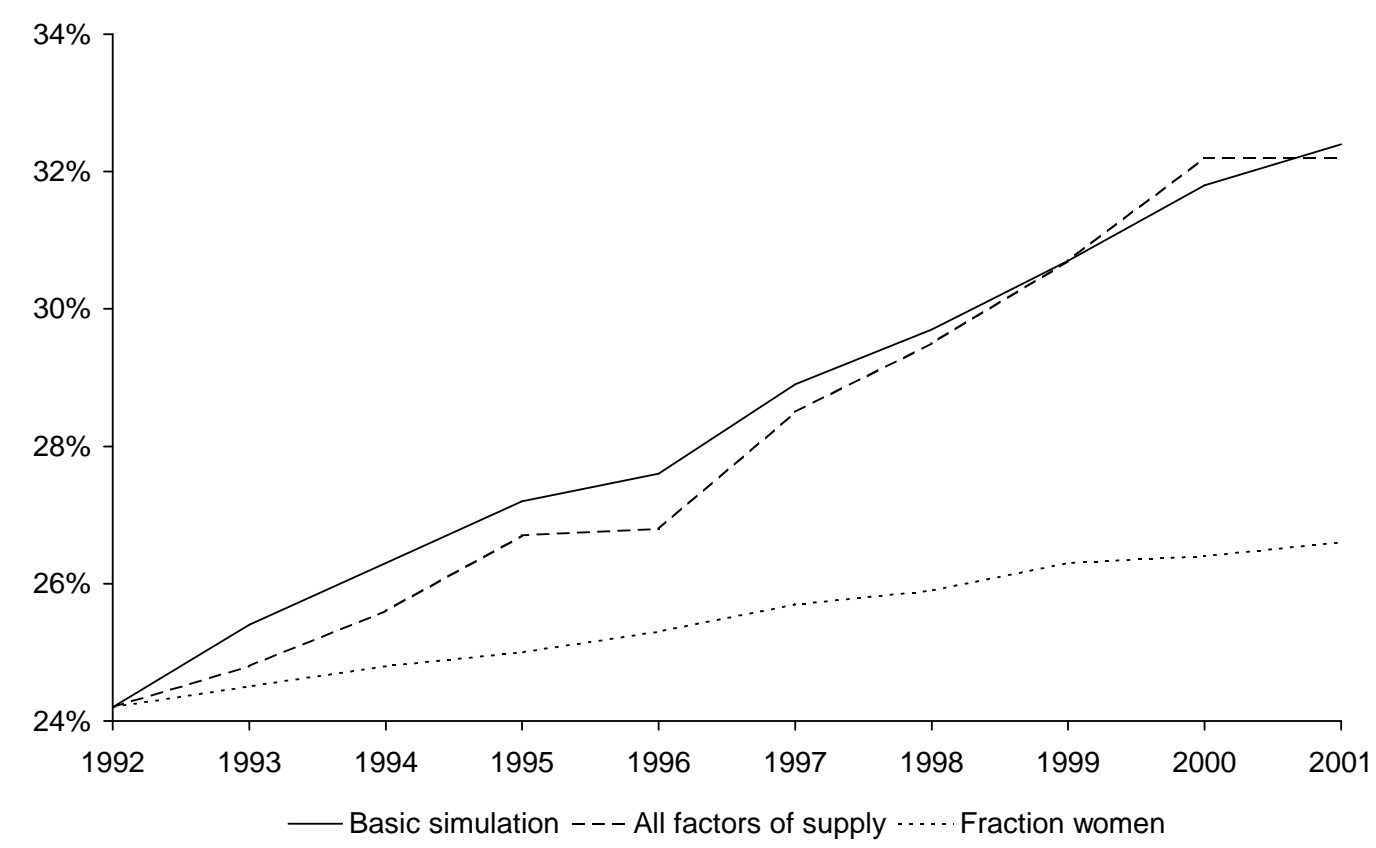

Figure 6.2: Simulated development of part-time employment, demand side

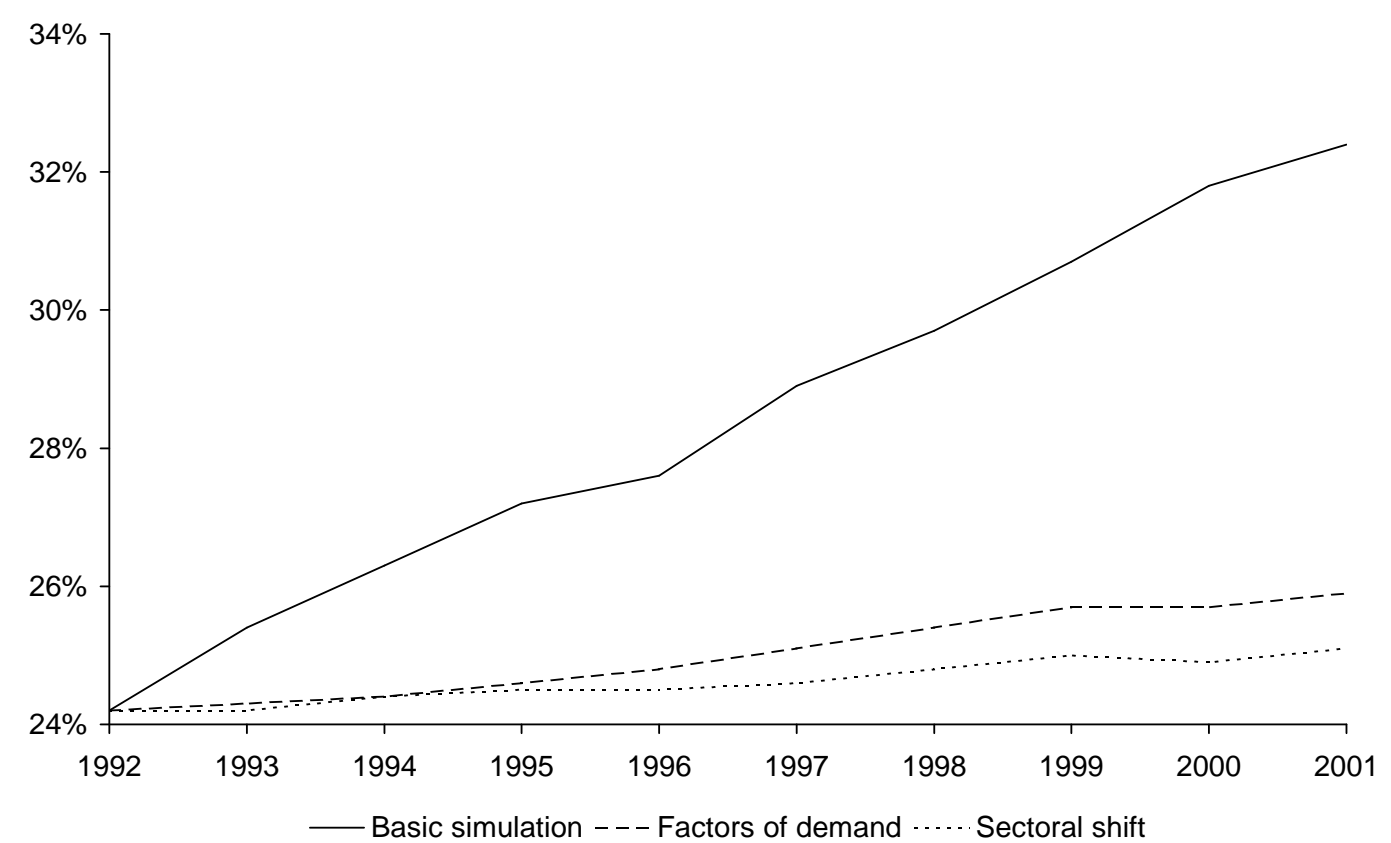

Note: 'basic simulation' predicts the development of part-time employment on the basis of the development of the observed exogenous variables. The simulation 'all factors of supply' keeps all exogenous variables constant since 1992, except for the variables on labour supply. The simulation 'fraction of women' keeps all exogenous variables constant since 1992, except for the variable on the fraction of women. The simulation 'factors of demand' keeps the variables on the business cycle constant since 1992 as well as the business cycle should have lead to a decrease in the rate of part-time employment. 


\section{Simulations}

The estimation results in Tables 6.1 and 6.2 show which variables significantly relate to parttime employment, but the results are less insightful for the question which variables are most relevant. We present a number of simulations to show how changes in the factors of supply and demand relate to the growth of part-time employment. We could use both the results of single as the simultaneous equation model as we are interested in the impact of the exogenous variables on the rate of part-time employment. As the simultaneous equation model may not be accurate for the Dutch labour market we use the single equation model for our simulations.

Our first simulation ('basic simulation') gives the prediction of the reduced form model on the basis of the development of the observed exogenous variables. At the aggregated level, the predicted rate of part-time employment deviates at most $0.4 \%$-points form the observed rate of part-time employment. The average absolute prediction error is about $0.2 \%$-points. We design the simulations by keeping all variables (including the size of the sectors of industry) constant at their 1992 values, except for the variable(s) of interest.

Figure 6.1 shows that the factors of labour supply relate strongly to the increase in part-time employment. Keeping all other variables constant since 1992 still gives a strong growth of parttime employment. This suggests that the joint factors of labour demand hardly contributed the increase of part-time employment. The figure also shows that the changing gender distribution, keeping everything else constant since 1992, would have lead to an increase of part-time employment from $24.1 \%$ in 1992 to 26.6 in 2001 . This increase accounts for about $30 \%$ of the total increase in part-time employment, which is in line with the results of the descriptive analysis of Section 2.2.

As the business cycle reached its highest point at the end of the 1990s, the growth of production and the vacancy rate should have led to lower part-time employment rates by the end of the 1990s. But part-time employment grew despite the business cycle. To isolate the effect of the other labour demand variables, we also simulate the effect of evening and weekend production, capital intensity and the shift between industries by allowing the size of industries to change since 1992. According to this simulation, see Figure 6.2, part-time employment would have grown from $24.1 \%$ in 1992 to $25.9 \%$ in 2001 . This accounts for about $20 \%$ of the growth in part-time employment. In a second simulation we isolate the impact of the sectoral shift. Parttime employment would have grown from $24.1 \%$ in 1992 to $25.1 \%$ in 2001, which is about $8 \%$ of total growth. So also in this respect the result are in line which the results of the descriptive analysis of Section 2.2 . 


\section{$7 \quad$ Conclusion and Discussion}

The Dutch labour market shows a high rate of part-time employment, and the rate continues growing at a pace faster than for any other European country and the US. In this study, we investigate the driving forces behind this growth. Most studies on working hours and part-time employment focus on the supply side and in particular on the increasing participation rate of women. We investigate the importance of factors of labour demand as well.

Descriptive statistics derived from the Dutch Labour Force Survey 1991-2001 reveal that the growth in part-time employment indeed strongly relates to the growth in female labour force participation. The shift between sectors of industries, from manufacturing to services, explains a part of the growth in part-time employment as well. Although factors of labour supply seem to play a major role, conclusions on the basis of partial effects ('cross-tabulations') are premature. Other factors may play a major role as well. In this study, we consider additional factors of labour demand for part-time employment: firms may need flexibility to adjust to the business cycle ('dynamic flexibility') and firms may need flexibility to meet the growing demand for goods and services at non-standard working times ('organisational flexibility'). To investigate the importance of the different supply and demand factors simultaneously we formulate a macro-econometric model at the sectoral level of industry.

Considering factors of labour demand, it is clear upfront that adjustments to the business cycle cannot explain the growth of part-time employment in the Netherlands: during the end of the 1990s economic growth was high and firms and employees should have adjusted towards fulltime employment. But organisational flexibility can be an important explanation for the growth of part-time employment as the service sector has been growing and the laws on opening hours have been liberalised. Our estimation results of the macro-econometric model confirm the importance of organisational flexibility as the increasing demand for labour in evenings has increased the rate of part-time employment.

The international literature on human resources management and industrial relations reports an increasing demand and use of flexible work arrangements as well and partly relates this to parttime employment (see for instance Zeytinoglu (1992)). The increasing demand for flexible working arrangements is however an international phenomenon and it is hard to find arguments on why this should be more important for the Netherlands than for other countries. So the need of firms for 'organisational flexibility' it is unlikely to be a major explanation for the rather high growth of part-time employment in the Netherlands compared to other countries. 
On the basis of our results, it seems obvious to conclude that that the high growth rate of parttime employment is largely caused by factors of labour supply, and in particular by the increasing female labour force participation. On the one hand, we have to be careful with the interpretation as it may be that female labour force participation in the Netherlands was encouraged by the increasing demand for (part-time) employment. The estimated impact of female labour force participation on part-time employment may therefore be biased upward. On the other hand, we just argued that it is hard to find factors of demand that explain why the growth of part-time employment is high in the Netherlands compared to other countries.

Therefore factors of labour supply are nevertheless like to be the major explanation for the high growth of part-time employment in the Netherlands.

\section{Literature}

Blank, R., 1989, The role of part-time work in women's labor market choices over time, American Economic Review, Vol. 79, Issue 2, pp. 295-299.

Bollé, P., 1997, Part-time work: solution or trap? International Labour Review, Vol. 136, No. 4, pp. 557-579.

Buchmueller, T., 1999, Fringe benefits and the demand for part-time workers, Applied Economics, Vol. 31, pp. 551-563.

Buddelmeyer, H., G. Moures and M. Ward, 2003, The determinants of part-time work in EU countries, mimeo, ECB.

Columbino, U. and M. Di Tommaso, 2000, Identifying demand and supply of part-time jobs using personnel data: an application to Italy, Labour, Vol. 14, No. 4, pp. 609-622.

Deardorff, A. and F. Stafford, 1976, Compensation and cooperating factors, Econometrica, Vol. 44, No. 4, pp. 671-684.

Doris, A., 1998, Married women in the Irish part-time labour market, The Economic and Social Review, Vol. 29, No. 2, pp. 157-178.

Ehrenberg, R., P. Rosenberg and J. Li, 1988, Part-time employment in the United States, in: Employment, unemployment and labor utilization, R. Hart (eds.), Boston. 
Euwals, R. and A. van Soest, 1999, Desired and actual labour supply of unmarried men and women in the Netherlands, Labour Economics, Vol. 6, pp. 95-118.

Fallick, B., 1999, Part-time work and industry growth, Monthly Labor Review, Vol. 22, pp. $22-29$.

Friesen, J., 1997, The dynamic demand for part-time and full-time labour, Economica, Vol. 64, Issue 255, pp. 495-507.

Grift, Y. and J.Siegers, 1993, Supply determinants of part-time work of Dutch married women: the influence of taxes and social premiums, Applied Economics, Vol. 25, pp. 1153-1160.

Hamermesh, D., 1993, Labor Demand, Princeton University Press, Princeton.

Hart, R., 1997, Working time and employment, Allen and Unwin, Winchester (Mass.).

Leppel, K. and S. Clain, 1988, The growth in involuntary part-time employment of men and women, Applied Economics, Vol. 20, pp. 1155-1166.

OECD, 1983, 1990, 1995, 2001, 2002, Employment Outlook, various issues.

Ressler, R., J. Watson and F. Mixon, 1996, Full wages, part-time employment and the minimum wage, Applied Economics, Vol. 28, pp. 1415-1419.

Rice, P., 1990, Relative labour costs and the growth of part-time employment in British manufacturing industries, Economic Journal, Vol. 100, Issue 403, pp. 1138-1146.

Tilly, C., 1995, Half a Job: Bad and Good Part-time Jobs in a Changing Labor Market, Temple University Press.

van Lomwel, G., 2000, Essays on Labour Economics, CentER Disseration Series, No. 75.

van der Wiel, H., 2001, Does ICT boost Dutch productivity growth, CPB Document, No. 16.

Zeytinoglu, I., 1992, Reasons for hiring part-time workers, Industrial Relations, Vol. 31, No. 3, pp. 489-499. 


\section{Appendix A: Dutch Labour Force Survey}

The Dutch Labour Force Survey (DLFS, 'Enquête Beroepsbevolking’) is administrated by Statistics Netherlands and is designed to monitor the labour force. The DLFS is a stratified sample from the population of Dutch inhabitants, excluding those that live in institutions.

The sampling procedure of the survey consists of two steps. In the first step, local communities are randomly drawn from the population of all local communities. Large local communities are included in the sample, while small communities are redrawn with probabilities that inversely relate to the number of addresses. In the second step, a certain number of addresses are randomly drawn for each local community. This step uses the Geographic Basic Register which is a list of all addresses in the Netherlands administrated by Dutch Telecom. Because of the stratification, the DLFS is not a random sample. Population means can be estimated by using weights that are provided together with the survey.

The DLFS contains detailed demographic and employment information. Employees provide information on their jobs (but not on salary) while non-employed provide information on their willingness to work and on their job search activities. In the 1990s, non-response rates vary between 40 and 45\%, the number of households varies between 45 and 65 thousand, and the number of individuals varies between 90 and 120 thousand individuals.

\section{Appendix B: Dutch Terms of Employment Survey}

The Dutch Terms of Employment Survey (DTES, 'Arbeidsvoorwaardenonderzoek') is administrated by the Dutch Ministry of Social Affairs and it is designed to monitor changes in terms of employment. The DTES is a stratified sample from the population of employees in the Netherlands, and it is based on the administrative record of a large number of firms.

The sampling procedure consists of two steps. In the first step, firms are drawn from the firm register of the ministry (which is roughly similar to the database of Statistics Netherlands). In the second step, a number of employees are drawn from the administrated records of the firms. The number of employees drawn depends on the size of the firm, and also on the number of employees that does not fall under a collective bargaining agreement. Because of the stratification, the DTES is not a random sample. Population means can be estimated by using weights that are provided together with the survey. 
The DTES contains detailed information wages and fringe benefits, and some information on demographic, socio-economic and firm characteristics. The number of firms is about 1800 per year, while the number of employees is about 45 thousand per year.

\section{Appendix C: Variables on Labour Supply}

Decisions on labour supply and part-time employment are made by individuals, and individuals take their family situation into account. As our empirical analysis in this study is on the sectoral level of industry, it is not easy to account for factors of labour supply. As we have only 11 years of observations, aggregated (macro-economic) variables on labour supply are unlikely to give good explanatory power. Ehrenberg (1988) uses sector specific labour supply variables like the fraction of women per sector as explanatory variables. The interpretation of these variables is however problematic as the direction of causality is unclear.

In this study, we use a weighting procedure to calculate sector specific labour supply variables. We construct labour supply variables on the basis of educational needs of a particular sector. The labour force of a sector will be defined on the basis the individuals that fulfil the educational needs of that sector. Note that this group of individuals will include individuals that are employed in other sectors and individuals that are unemployed. This prevents causality from the demand for part-time employment to labour supply as we do not consider individuals that may be working in a sector because they can work part-time in that sector. It does not prevent all problems of causality, as in the end individuals may have a certain education because they want to work part-time later on in their career.

Consider the employed in the Dutch Labour Force Survey (DLFS) with a number of $j=1, \ldots, N$ individuals. Define educational weight $\alpha_{i t}{ }^{e}$ for sector $i$ at time $t$ and level and direction of education $e$ as:

$\alpha_{i}^{e}=\frac{\sum_{j=1, \ldots, N} I\left(x_{j}^{i}=1, x_{j}^{e}=1\right)}{\sum_{j=1, \ldots, N} I\left(x_{j}^{i}=1\right)}$

with $\left(x_{j t}{ }^{i}, x_{j t}{ }^{e}\right)$ dummies for individual $j$ working in sector $i$ and having education level and direction $e$. The educational levels vary from 'basic education', 'lower vocational', 'medium vocational', 'higher vocational' to 'scientific education', while the directions vary from 'general', 'technical', 'economic', 'health care' to 'other'. We observe 20 combinations as not all combinations exist in the Dutch education system. To give some examples, a medium 
vocational education has a weight of 0.386 for the sector 'health care' and a weight of 0.016 for the sector 'agriculture'. Per sector the weights add up to one.

Next, consider the labour force (including unemployed) observed in the DLFS with a number of $j=1, \ldots, M$ individuals. Every individual gets per sector a weight attached that belongs to his or her kind of education. Define weight $\alpha_{i j t}$ for individual $j$ and sector $i$ at time $t$ :

$\alpha_{i j}=\sum_{e=1, \ldots, E} \alpha_{i}^{e} I\left(x_{j}^{e}=1\right)$

We use the individual weights to construct labour supply variables as weighted averages over the population of individuals that fulfil the educational need of a sector. For example, an individual with educational direction 'health care' will be important for the labour force of that sector, while the individual will be much less important for a sector like 'agriculture'. Define $x_{i t}{ }^{w}$ as the fraction of women in the labour force of sector $i$ at time $t$ :

$x_{i}^{w}=\frac{\sum_{j=1, \ldots, M} \alpha_{i j} I\left(x_{j}^{\nu}=1\right)}{\sum_{j=1, \ldots, M} \alpha_{i j}}$

with $x_{j}^{v}$ a dummy variable for individual $j$ on being a woman.

Besides the fraction of women in the labour force of a sector, we calculate the fractions of women that have certain ages and have children among the total female labour force. The same we do for men among the total male labour force. These variables allow for gender specific effects of age and children in the empirical analysis of Section 5. 